\title{
The Effectiveness Factor on Brand Strategy
}

\section{A Case Study on Taobao's Brand Perception for Generation $Z$}

\author{
Junqi Han ${ }^{1, \dagger}$, Xin Wang ${ }^{2, \dagger}$, Zihan Zhu ${ }^{3, *, \dagger}$
}

\author{
${ }^{1}$ Qingdao No. 58 School, Qingdao, China, 266100 \\ ${ }^{2}$ Xiamen Hubin High School, Xiamen, China, 361004 \\ ${ }^{3}$ Carmel Catholic High School, Vernon Hills, IL, American, Chicago, U.S.A., 60060 \\ *Corresponding author. Email: zzhu.2024@carmelhs.org \\ These authors contributed equally.
}

\begin{abstract}
Taobao is a promise of platform, a representative of e-commerce, a famous brand that offers a place for merchants and customers to sell and buy. It is Taobao that has opened up a new era of e-commerce and brought it into people's vision. Therefore, it is important to learn about how Taobao opened up that new era successfully and apply it to new ecommerce, especially in today's Chinese market. Generation Z rises as consumers, who were born with access to the Internet. As the leader in many e-commerce platforms, Taobao has its unique brand perception for Generation $\mathrm{Z}$. Knowing what brand strategies Taobao has used would be significante for China's future development. This research focus more on Generation Z's brand perception of Taobao, how Taobao's brand awareness, and brand association would influence its brand loyalty? This paper further develops Aaker model by changing the relationship between Independent and dependent variables of the model in the structure model which start a new research direction of branding strategy. The paper used questionnaire survey to investigate Generation Z's perception of Taobao's brand loyalty, brand awareness, and brand association.
\end{abstract}

Keywords: Taobao, e-commercial market, brand loyalty, brand awareness, brand association, survey.

\section{INTRODUCTION}

The development of e-commerce has altered the way of purchasing around the world. Especially in China, it is still a sector that grows rapidly, as consumer behavior starts to change rapidly in China, e-commerce has to update at a very fast rate, which also means through ecommerce, people are able to feel breath of the epoch.

Chinese e-commerce is provided with great financial support, Taobao is a good example, it has the financial backup of Alibaba. In China's current e-commercial market, the situation of product surplus is serious. Every e-commercial seller wants to sell their products quickly, they would put various products on the market in order to prevent this situation. But this needs consumers to be willing to spend their money on these products, which they actually do. In China, the consumer craze seems to have surpassed this kind of surplus. For example, China's middle bourgeoisie has reached a certain degree of affluence, these consumers usually own their own houses and now want to buy various products for their families, although they would still pay attention to whether the product worth the money, they have more choices of goods that they want to buy. It seems that Chinese ecommerce is in a very positive and growing period.

However, hidden dangers always lurk in rapid development. At present, many shell companies sneak into many online shopping platforms, while the regulatory system is not complete enough. Also, Generation $\mathrm{Z}$ does not have the ability to detect these fake companies, which means the regulatory system of ecommerce will become the key to its future, otherwise more and more Generation $\mathrm{Z}$ would be defrauded. Whether China's e-commerce can last long or not in the current market depends a lot on the changes of the regulatory system by Taobao and other e-commerce platforms. The popularity of Taobao seems to offer a very good opportunity for them. Taobao is a leading online 
C2C auction company, a promise of the trading platform. Many services launched by Taobao have become popular terms and entered our language, and these terms, are especially popular among Generation Z.

Generation $\mathrm{Z}$ was born and raised with access to the Internet, new technologies are very natural in their living environment. With their own mobile devices, they are able to have multiple shopping platforms on their mobile devices in order to compare the price and quality of goods. The pursuit of personality also lets them purchase from a different perspective; the consideration of price generally comes second. They think that the feedback about the results of their work is very important, they can change their jobs very easily, but they are also very willing to work for an employer for a very long period under the condition that the job is attractive.

Based on current research, Taobao is now mainly targeting Generation Z. Generation Z's consumer philosophy is "Gen $\mathrm{Z}$ is looking more for this item that shows that they're different, they're unique" Generation $\mathrm{Z}$ prefers to shop "going online" [1]. The research question in this article is: what kind of Brand Strategy can be used to increase Generation Z's loyalty to Taobao. This paper hypothesizes that Taobao's Brand awareness and brand association have a positive impact on Generation Z's brand loyalty. The target population chosen for this paper is generation $\mathrm{Z}$ who are living in China and are still students. Taobao's use of current strategies for the Generation $\mathrm{Z}$ demographic will have a positive impact on this demographic. For example, it will drive visits and transactions. After obtained the results of the questionnaire, this paper used an excel spreadsheet to analyze the data and present it in graphs. In order to verify the idea, this study took a questionnaire to investigate the Taobao brands of the Generation $\mathrm{Z}$ group. This paper randomly distributed questionnaires and conducted a random survey. The study divided the whole paper into four parts of research and investigation for the hypothesis. The first part is a theoretical study, for example. The second part is the collection of data and the analysis of the collected data. The third part is an in-depth discussion based on the data analyzed. The fourth part is a summary of the entire article on Taobao's brand strategy and strategic results.

\section{LITERATURE REVIEW}

\subsection{History of TAOBAO}

The founder of Taobao is Jack Ma. He is a very inspirational being who has gone from obscurity to the position of the richest man in China. As early as April 2003, Jack Ma and 10 employees in Hangzhou to plan the construction of Taobao.com, May 10, 2003, Taobao was officially established, Taobao just online at the beginning to July 4, 2003, the site rapid development, the daily addition of more than 2,000 new products, in August
2003, Taobao announced free 3 years, attracting a large number of small and medium-sized sellers to the station. On December 31, 2010, Taobao had more than 370 million registered members, accounting for $80 \%$ of China's online shopping market. In 2012, the transaction volume of Taobao and Tmall.com exceeded RMB 1 trillion, more than the sum of Amazon.com and eBay. Taobao has more than 60 brands of values, but the most important to Taobao is the Taobao.com promotes a culture of honest, active, and fast online transactions. Taobao's headquarters is located in Hangzhou, Zhejiang Province, China, and Taobao has about 8,000 employees working here. Taobao provides a platform for consumers to choose products from different sellers, ask wholesalers and retailers for refunding, make comments, and display the products they received, to open their own personal stores on its platform. Consumers are able to get clothes, accessories, gadgets, computer hardware at very low prices, they can even buy pets and second hands stuff.

Factors like brand awareness, association, loyalty will be discussed in this section.

\subsection{Brand Awareness}

Brand awareness is a super definition including brand acquaintance, potential of being remembered, information and the ideas about the product [2]. Brand awareness is associated with the information node in the memory; the ability of customers to recognize a brand under a variety of conditions reflects their awareness of the brand [3]. Brand awareness as the brand recognition and brand recall of a brand [4]. Brand awareness creates a great association in memory about a particular brand [4]. Brand awareness is one of the main factors in creating brand added value and is also considered as one of the key factors affecting the knowledge: level of consumers about the brand [5].

\subsection{Brand Association}

Brand association is defined as the strength of benefits offered by the brand. "Brand association" can be used as a 1 general term to represent a link between two nodes, which suggest brand association in customers mind" [8]. Brand association would help consumers search and deal with information [9]. Moreover, brand association would provide consumers with a purchasing reason, because most brand associations are related to brand attributes, the target consumer market, and the benefits that consumers need, so that they form the foundation of brand loyalty and consumers' purchasing decisions [10].

\subsection{Brand Loyalty}

Brand loyalty as symbolizes a constructive mind set toward brand that leading to constant purchasing of the brand over time [11]. Aaker also argues that brand loyalty 
is an essential element when it comes to evaluate a brand in terms of value because loyalty can generate profit. There are two approaches being used to understand the brand loyalty that have completely outclassed in the marketing literature [12,13]. The first approach in marketing literature is behavioural approach to brand loyalty in which the advocators believe that constant purchasing of one brand over time is an indicator of brand loyalty. The second approach in the marketing literature is cognitive approach to brand loyalty in which the advocators argue that behaviour solely does not reflect brand loyalty. Brand loyalty has the power to impact on customer decision to purchase the same product or brand anddecline to shift to competitors' brands [14]. As a result, brand loyalty is the core of brand's value [14].

This paper finally decides to use the Aaker's theory about branding, which is fit the research background-the e-commercial market and the research object-Taobao, so in this study, the paper chosen this theory as the theory basis and analytic demonstration.

\section{METHOD}

In order to test the hypothesis of the question "What kind of Brand Strategy to increase Generation Z's loyalty to Taobao" presented in this article, the paper hypothesized that Taobao's Brand awareness and association have a positive impact on Generation Z's brand loyalty is positively influenced by Taobao's brand awareness and association, so this paper designed a validation method. The validation method the paper used was a questionnaire survey in Generation Z. The survey approach has been used in a number of previous studies on similar issues "Chinese customer satisfaction of online shopping of Taobao is surveyed in the empirical study" [17]. At the same time, the scope of the questionnaire proposed in this article is for Generation $\mathrm{Z}$, so the questionnaire is developed in this scope, which makes the analysis of the proposed question more effective. After 5 days, the survey received 52 effective questionnaires, with an effective rate of $91 \%$. Since Taobao's main marketing scope is in mainland China, the general scope of this study is Generation $\mathrm{Z}$ who are born and raised in China without independent economic resources.

\section{RESULTS}

The paper analyzes the Taobao's survey by using linear regression model, here is the summary output. The paper uses regression analysis to analyze the relationship of the variables involved. The Variable $\mathrm{Y}$ is brand loyalty while the two $\mathrm{X}$ variables are brand awareness and brand association.
Table 1 : Regression Statistics

\begin{tabular}{|l|l|}
\hline \multicolumn{2}{|l|}{ Regression Statistics } \\
\hline Multiple R & 0.754211303930907 \\
\hline R Square & 0.868834690977159 \\
\hline Adjusted R Square & 0.75123610693541 \\
\hline Standard Error & 0.742761942785378 \\
\hline Observed Value & 52 \\
\hline
\end{tabular}

Table 2: Regressive analysis

\begin{tabular}{|c|c|c|c|c|c|}
\hline \multicolumn{6}{|c|}{ Variance Analysis } \\
\hline & df & SS & MS & $\mathrm{F}$ & $\begin{array}{c}\text { Significance } \\
\text { F }\end{array}$ \\
\hline $\begin{array}{l}\text { Regressive } \\
\text { Analysis }\end{array}$ & 2 & $\begin{array}{l}35.664622 \\
4288271\end{array}$ & $\begin{array}{l}17.832311 \\
2144136\end{array}$ & \begin{tabular}{|l}
32.32 \\
27533 \\
32184 \\
4
\end{tabular} & $\begin{array}{l}0.00000000 \\
1118853862 \\
64445\end{array}$ \\
\hline Residual & 49 & $\begin{array}{l}27.033069 \\
8788652\end{array}$ & $\begin{array}{l}0.5516953 \\
0365031\end{array}$ & & \\
\hline Total & 51 & $\begin{array}{l}62.697692 \\
3076923\end{array}$ & & & \\
\hline
\end{tabular}

The regression statistics include Multiple $\mathrm{R}, \mathrm{R}$ square, adjusted $\mathrm{R}$ square, standard error, and observed value. Multiple $\mathrm{R}$ shows the correlation coefficient $\mathrm{R}$ of $\mathrm{X}$ and $\mathrm{Y}$, the closer the absolute value is to 1, the stronger the correlation is, also, the closer the absolute value is to 0 , the weaker the correlation is. In this case, the Multiple $\mathrm{R}$ reaches 0.754211303930907 , closes to 1 , which means that it has a fairly high relevance. For $\mathrm{R}$ square and adjusted $\mathrm{R}$ square, they represent the fitting degree of data and model (Table $1 \&$ Table 2), both of the model is larger than 0.5 , so the fitting degree of the model is high. The observed value is 52 , which may cause the standard error fairly high, given that the time is limited, this could be improved later. In this case, the standard error is lower, the accuracy of the parameters would be higher. T Stat is used for the test of model parameters and in this model, the confidence interval reaches $95 \%$. P-value refers to the probability that the statistical results are larger than the actual observation data in the model, which is when the original hypothesis is true, the probability that the results are more extreme than the sample observation result. While in the model (Table 3), the P-value of the first variable, brand awareness, is larger than 0.05 , which is not significant. Brand awareness, in this case, is not significant to brand loyalty. The P-value of the second variable, brand association, is less than 0.001 , which is extremely significant, brand association is very 
significant to brand loyalty. Overall, the P-value of the model is less than 0.05 and larger than 0.01 , so the model would be highly significant.

Table 3: P-Value

\begin{tabular}{|l|l|l|}
\hline & Coefficients & P-value \\
\hline Intercept & 0.7166545 & 0.00198553 \\
\hline X Variable 1 & 0.2026248 & 0.22379906 \\
\hline X Variable 2 & 0.58343015 & 0.00067037 \\
\hline
\end{tabular}

\section{DISCUSSION}

The results demonstrate that Taobao's brand perception is very broad in terms of Generation Z. It is important to highlight the fact that most of Generation $\mathrm{Z}$ are students with most of their income coming from their family, they usually have multiple shopping platforms in order to compare products. Three-quarters of them would consider Taobao as their platform to purchase products, and when they need to recommend shopping platforms to their friends, most of them would consider Taobao as their first option. However, if there happens to be a shopping platform that has more preferential advantages, they are likely to switch to that platform instead of choosing a single shopping platform. As for Taobao's services, although Generation $\mathrm{Z}$ would still think of Taobao's service as the symbol of quality service, an important question associated with this is that compared to Taobao's early services, Taobao's quality of service is declining. It is worth discussing these interesting facts revealed by the results that Generation $\mathrm{Z}$ would consider Taobao as the ancestor of online shopping platforms. Generation Z's perception of Taobao is influenced by its ancestor and leading position, although many of them don't use T-mall, they still heard of it because of Taobao. Therefore, Taobao's Brand awareness, and association indeed have a positive impact on Generation Z's brand loyalty. For Taobao, is that they are able to have better development in the future by paying attention to Taobao's brand awareness, and brand association. This paper has done the survey in a different way compared to the former study; this study did the survey with more weight to their feelings. However, compared to previous studies, the paper did not have enough feedback, given the fact that the time permitted is limited.

\section{CONCLUSION}

In this paper, it has done a case study on Taobao. In order to solve the question "What kind of Brand Strategy to increase Generation Z's loyalty to Taobao?", this paper used a questionnaire to collect data about Generation Z's loyalty to Taobao, and then this study systematically analyzed the collected data. According to the analysis, it could be seen that Taobao's Brand
Awareness and Brand Association can increase Generation Z's loyalty to Taobao. According to the data from the questionnaire, Brand Awareness makes Generation $\mathrm{Z}$ remember the brand more and use the brand more. The case study in this paper takes Taobao as having some special characteristics and is too representative for the Chinese market. But whether Taobao is still universal in the Chinese e-commerce market, this paper needs to study this issue more in the future. Taobao is a brand for the Chinese market, but do not know whether foreign ecommerce brands, such as Amazon, have the same influence and status. According to the research question, this study only did a questionnaire and the data is somewhat quantitative. In the future, more data can be collected on the loyalty of Generation $\mathrm{Z}$ to Taobao. The sample size of this paper is too small and could be extended and actively promoted in the future. The target area of this survey is not very popular, most of the respondents are around Jiangsu, Zhejiang, and Shanghai, and this range of collection targets may have some geographical influence on the collected data. This study of brand loyalty is theoretically not only influenced by Brand Awareness and Brand Association, but also by many other factors, such as brand publicity, which are not studied in this paper. Nowadays, the e-shop market has a very important influence in China. Customer loyalty to a brand can be considered a key factor for brand success. This paper provides many ways to help Taobao to enhance the user stickiness of its customers. Firstly, increasing Brand Awareness and Brand Association of the brand makes Taobao a popular choice among eshoppers with many brands. Second, Generation Z is becoming a major player in the e-marketplace. This study investigates the online shopping loyalty of Chinese Generation $\mathrm{Z}$ to Taobao, and this study had obtained a lot of data to support it. Due to the special nature of ecommerce shopping, in the future, the study will also need to study this issue for a long time. Taobao should begin to improve its internal services based on the data collected, so that Generation Z's loyalty to Taobao can increase.

\section{REFERENCES}

[1] Finneman B., Rahilly L., \& Spagnuolo E, Meet Gen eration Z: Shaping the future of shopping, 2020.

[2] Bilgili B., \&Ozkul E., Brand Awareness, Brand Pers onality, Brand Loyalty and Consumer Satisfaction Relations in Brand Positioning Strategies (A Torku Brand Sample), Journal of Global Strategic Manag ement, 9(2), 2005, pp. 89106. DOI: $10.20460 / J G S M .2015915576$

[3] Ekhveh A., \& Darvishi A.Z., The Impact of Brand A wareness on Repurchase Intention of Customers W ith Trilogy of Emotions Approach (Case Study for Cell Phones), Applied mathematics in Engineering, 
Management and Technology, 3(4), 2015, pp. 2530 .

[4] Malik M. E., Ghafoor M. M., Hafiz K. I., Riaz U., H assan N. U., Mustafa M., \&Shahbaz S., Importance of brand awareness and brand loyalty in assessing purchase intentions of consumer, International Jour nal of Business and Social Science, 4(5), 2013, pp. 167-171.

[5] Ekhveh A., \& Darvishi A.Z., The Impact of Brand A wareness on $\mathrm{Re}$ -

purchase Intention of Customers with Trilogy of E motions Approach (Case Study for Cell Phones), A pplied mathematics in Engineering, Management a nd Technology, 3(4), 2015, pp. 25-30.

[6] Jamil B., \& Wong C. H., Factors influencing repurch ase intention of smartphones, Journal of Marketing Research, 4(12), 2010, pp. 289-294.

[7] Krishnan H.S., Characteristics of memory associatio $\mathrm{n}$ : A customer- based brand equity perspective, Inte rnational Journal of Research in Marketing, 13, 199 6, pp. 389-405 DOI: 10.1016/S01678116(96)00021-3

[8] Chen A.C.H., Using free association to examine the relationship between the characteristic of brand ass ociation and brand equity, Journal of Product \& $\mathrm{Br}$ and Management, Decision Processes, 50(2), 2001, pp. 179-211. DOI: 10.1108/10610420110410559

[9] Boisvert J., Conceptualization and modelling of the process behind brand association transfer, Internati onal journal of Market Research, 53(4), 2011, pp. 5 41-556 DOI: 10.2501/IJMR-53-4-541-556
[10] Len T.W., Cindy M., Lynn M.M., Research issues i $\mathrm{n}$ building brand equity and global brands in the $\mathrm{P}$ C market, Journal of Marketing Management, 3(1), 2007, pp. 137-

155. DOI: $10.1362 / 026725707 \mathrm{X} 178602$

[11] Aaker D. A., Managing brand equity, New York: T he Free Press, 1991.

[12] Assael H., Consumer behavior and marketing actio n, Boston: PWS-Kent Publishing, 1992.

[13] Samuelsen B. M., \& Sandvik K., The concept of cu stomer loyalty, The 25th EMAC Conference, Univ ersity of Warwick, UK, 1997.

[14] Yoo B., Donthu N., \& Lee S., An examination of s elected marketing mix elements and brand equity, $\mathrm{J}$ ournal of the Academy of Marketing Science, 28(2 ), 2000, pp. 195-

211. http://dx.doi.org/10.1177/0092070300282002

[15] Yoo B., Donthu N., \& Lee S., An examination of s elected marketing mix elements and brand equity, $\mathrm{J}$ ournal of the Academy of Marketing Science, 28(2 ), 2000, pp. 195-

211. http://dx.doi.org/10.1177/0092070300282002

[16] Strategic Marketing \& Research Techniques, Brand and image assessment, 1992-2008.

[17] Yue Liang., Chinese customer satisfaction survey o f online shopping: a case study of Taobao, 2012. 